\title{
Adverse factors affecting growth of schoolchildren in St. Helena
}

\author{
C. D. MOYES
}

\begin{abstract}
Moyes, C. D. (1976). Archives of Disease in Childhood, 51, 435. Adverse factors affecting growth of schoolchildren in St. Helena. More than 1000 schoolchildren on St. Helena were studied to determine factors associated with suboptimal growth. Disease was demonstrable in only a small minority, but social factors were of prime importance. In particular, family size was found to be a dominant factor, over-riding the associated effect from overcrowding. The implications of this finding are discussed, and the concept of a 'threshold of coping' developed. It is suggested that failure to achieve optimal growth may be a particularly useful index of the points of stress in the child-rearing patterns of society.
\end{abstract}

This paper forms part of a wider survey which attempted to assess the health and welfare of children on St. Helena. Growth was considered as one of the indices of health in the population. The material here presented attempts to explore the major correlations with poor growth, with particular emphasis on social factors.

St. Helena is a small volcanic island in the mid-Atlantic Ocean. It has a healthy climate. The population numbers about 5000 of mixed stock, with no separable racial groupings. Culture is entirely English. Nutrition is of Western type with overloading of carbohydrates. There is no frank protein-calorie malnutrition, and no definite vitamin deficiencies in schoolchildren. There are no tropical diseases, but a Western pattern of morbidity with diabetes, atherosclerosis, and cancer the major causes of adult mortality. Infant mortality is less than $1 \%$, and deaths among schoolchildren are very rare. There is universal free health care and universal schooling from 5-15 years.

\section{Method}

All children attending school during early 1973 were examined. Social information was provided by teachers (who knew the families well) and parents, and checked by the health visitor. The medical record of each child from birth was examined. The exclusions from the survey were absentees $(<5 \%)$, expatriates, children over 15 years old (February 1973), and one family with mental retardation and ichthyosis. Included were 1128 children, at least $95 \%$ of all native born St. Helenians, in the age range of 5-15 years.

Received 13 October 1975.
Each child was measured in stockings and light underclothes, and height and weight tabulated according to nearest centile, using standard charts of Tanner, Whitehouse, and Takaishi (1966) for English schoolchildren. Information relating to poor growth was analysed at two levels: (1) below 3rd centile, (2) below 16 th centile, approximately -1 SD. The use of the 16 th centile was intended, when compared to the group below the 3rd centile, to clarify more general factors acting in a multifactorial situation, which may contribute significantly to suboptimal growth. Every child below the 3 rd centile was investigated by a blood count, blood urea and urine tests; also electrocardiogram, chest $x$-ray, and bone age if appropriate. All cases of serious disease in the past or present were excluded from the social analysis.

\section{Results}

Suitablity of centile charts. Healthy St. Helenian schoolchildren are smaller in height and lighter weight than their English counterparts (Table I). Nevertheless the centiles form a standard which enable the children of poorer growth to be identified.

\section{TABLE I}

Height and weight of healthy St. Helenian schoolchildren (total no.=1073) compared with English centile standards (Tanner et al., 1966)

\begin{tabular}{|c|c|c|c|c|}
\hline & \multicolumn{2}{|c|}{ Weight } & \multicolumn{2}{|c|}{ Height } \\
\hline & No. & $\%$ & No. & $\%$ \\
\hline $\begin{array}{l}<16 \text { th centile } \\
<3 \text { rd centile }\end{array}$ & $\begin{array}{r}394 \\
50\end{array}$ & $\begin{array}{r}36 \cdot 6 \\
4 \cdot 7\end{array}$ & $\begin{array}{r}275 \\
50\end{array}$ & $\begin{array}{r}25 \cdot 6 \\
4 \cdot 7\end{array}$ \\
\hline
\end{tabular}


Pathological factors. A minority of the smaller children had demonstrable physical disease-only $8 / 58(14 \%)$ children below the 3 rd centile in stature (Table II). These results are similar to

TABLE II

Contribution of recognizable physical disease to poor growth in St. Helenian schoolchildren

\begin{tabular}{l|c|c}
\hline & Weight & Height \\
\hline Total no. <16th centile & 425 & 298 \\
No. $<16$ th centile with disease & $31(8 \%)$ & $23(8 \%)$ \\
Total no. $<3$ rd centile & 64 & 58 \\
No. $<3$ rd centile with disease & $14(22 \%)$ & $8(14 \%)$ \\
& & \\
\hline
\end{tabular}

those of Lacey and Parkin (1974a) who found only 16/98 Newcastle children below the 3rd centile stature to have physical disease. In children below the 16th centile for weight or height, among whom multifactorial genetic and environmental influences are of greater importance, physical disease was present in only $8 \%$. Prominent among the pathological causes of growth retardation were asthma, congenital heart disease, and 4 cases of skeletal dwarfism (having characteristic features and very short stature; see Shine, 1970).

\section{Physical characteristics.}

Race. There has never been a truly indigenous population, the major contributions to the island's population having been English and West African, with smaller infusions of other races, including Chinese. Intermixing has been remarkably complete and there are no separable racial groups (excluding expatriates), though there are a few individuals with more dominant Caucasian or African features at the extremes of the spectrum. There were no children with predominantly Oriental features.

It was impossible to allow for racial effects quantitatively, but the vast majority of children of smaller stature were of indefinable racial type and the few with characteristics nearest to one race or the other were not prominent in either small or large stature. There is uniformity of culture, including social structure, dietary and child-rearing practices.

Sex. There was no significant difference between the sexes in prevalence of children below the $3 \mathrm{rd}$ or 16 centiles.

Age. There was a slightly smaller proportion of older children below the 3rd and 16th centiles, probably related to the much wider spread of the centiles in the pubertal age group. It is of interest that the association of suboptimal growth with social factors (see below) was also reflected in the fact of later menarche observed in the same groups.

\section{Social factors.}

Background. The upbringing of children in St. Helena is essentially similar to that in Western societies, except for the operation of a more extended family. Hence first- and second-degree relatives may aid in the care of a child. The mother's mother is an important figure, often living under the same roof. However, the situation is nearer to that of a close-knit rural society in England where reponsibilities outside the direct line of descent are small, than to the much wider concepts of family duties exemplified, for example, in West African tribal groups (e.g. Igbo). Indeed there is a children's home containing about 15 children (omitted from figures below) whose parents are dead or unable to care for them. In most cases where child care is taken over by a substitute mother, the latter is the maternal grandmother. Older girls in a family are expected to help with the younger children.

The typical house is a single storey cottage onto which new rooms are built in a longitudinal series as the household population increases. The rooms are often only partly separated, each room opening both to the outside, and to its neighbours. In some areas two storey houses or modern flats are more usual. It is common for several generations of a family to share the same home, and for several members (often of different generations) to sleep in the same room.

Only children with no physical abnormalities were considered in the social part of the study.

Social class. Using a simple division according to father's occupation there is no significant association between poor growth and social class (Table III). This is in marked contrast to English

\section{TABLE III}

Prevalence of poor growth related to social class of father among St. Helenian schoolchildren

\begin{tabular}{|c|c|c|c|}
\hline & Clerical & Skilled & Unskilled \\
\hline $\begin{array}{l}\text { Total } \star \\
\text { Weight }<16 \text { th centile }(\%) \\
\text { Weight }<3 \text { rd centile }(\%)\end{array}$ & $\begin{array}{l}79 \\
36 \cdot 7 \\
3 \cdot 8\end{array}$ & $\begin{array}{r}255 \\
33 \cdot 3 \\
3 \cdot 1\end{array}$ & $\begin{array}{r}526 \\
40 \cdot 5 t \\
6 \cdot 1 \dagger\end{array}$ \\
\hline $\begin{array}{l}\text { Height }<16 \text { th centile }(\%) \\
\text { Height }<3 \text { rd centile }(\%)\end{array}$ & $\begin{array}{r}24 \cdot 0 \\
5 \cdot 1\end{array}$ & $\begin{array}{r}26 \cdot 3 \\
2 \cdot 7\end{array}$ & $\begin{array}{r}27 \cdot 5 t \\
5 \cdot 5 t\end{array}$ \\
\hline
\end{tabular}

$\star$ Total information available for 860 .

†Not significant. 
studies (Miller, Billewicz, and Thomson, 1972; Neligan, Prudham, and Steiner, 1974), and may reflect the greater uniformity of social and cultural norms on St. Helena.

Household size. This was defined as the total number of people living in the same house; homes containing more than one family with children under 15 years were excluded. The proportion of children from each size of household below the 3rd and 16th centiles is shown in Fig. 1. Comparing children from three groups of household size $(<5,5-10,>10)$, there is a progressively greater proportion of children below the 3rd centile for both weight and height in the larger households (weight $\chi^{2}=5 \cdot 90, P<0.05$; height $\chi^{2}=7 \cdot 45$, $P<0 \cdot 05)$. This is also true when the 16th rather than the 3rd centile is used for analysis (weight $\chi^{2}=16 \cdot 62, \mathrm{P}<0 \cdot 01$; height $\left.\chi^{2}=10 \cdot 49, \mathrm{P}<0.01\right)$.

In the absence of frank nutritional deficiencies or of any clearly separable racial or cultural grouping which could account for this effect of household size, it was felt worth while to explore the relation between poor growth and family size.

Family size. The nuclear family was defined as a mother and all her children less than 15 years old. Homes containing more than one such family were excluded. The proportion of children from each size of family who were below the 3rd and 16th centiles is shown in Fig. 2. Comparing three

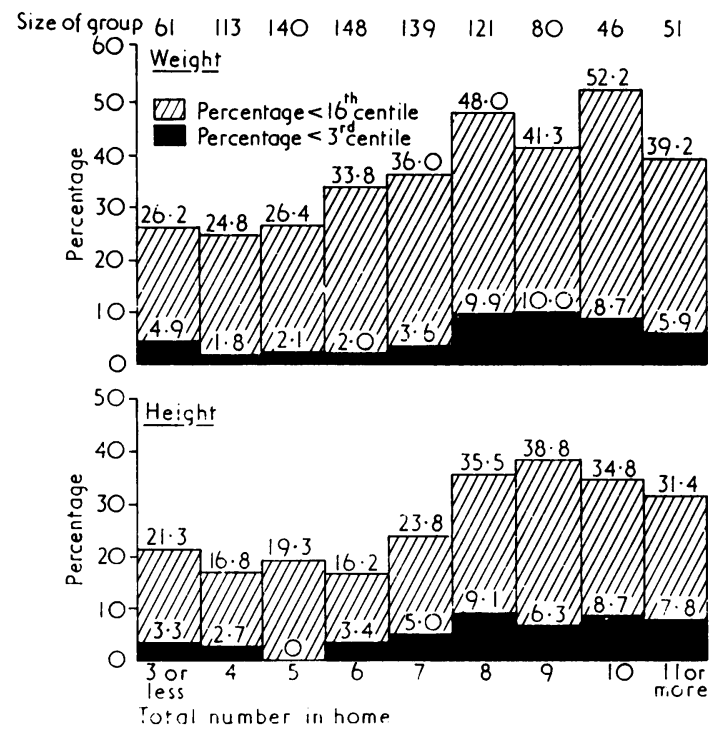

Fig. 1.-Percentage of children in $<3 r d$ and $<16$ th growth centiles related to numbers living in the same home.

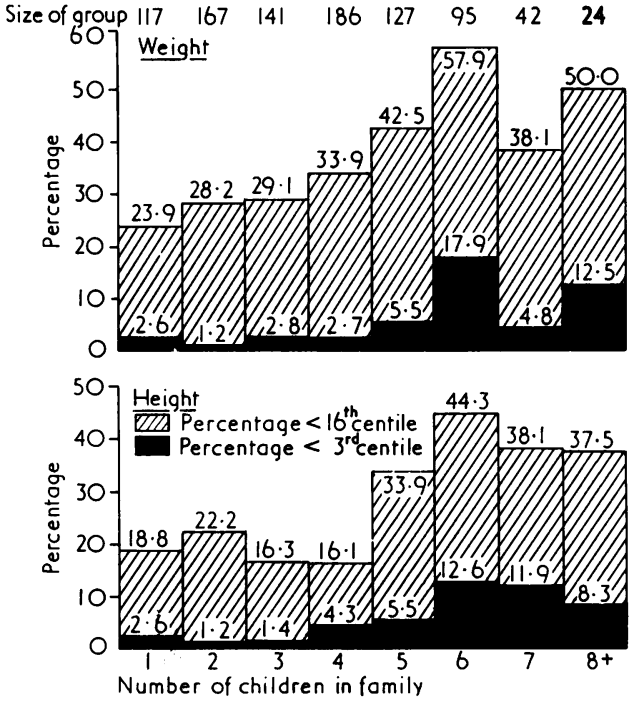

FIG. 2.-Percentage of children in $<3 r$ and $<16$ th growth centiles related to size of nuclear family.

groups of family size (no. of children 1-3/4-5/>5), there is a striking increase in the proportion of children below the 3rd centile for both weight and height in the larger families (weight $\chi^{2}=33.5$, $\mathrm{P}<0.001$; height $\left.\chi^{2}=26.4, \quad \mathrm{P}<0.001\right)$. This finding of markedly poorer growth in larger families is also seen when the 16th centile level of analysis is used in the same way (weight $\chi^{2}=20 \cdot 2$, $\mathrm{P}<0.001$; height $\left.\chi^{2}=26 \cdot 6, \quad \mathrm{P}<0.001\right)$. These results show a much more convincing link with family than with total household size. Furthermore, there is a particularly steep increase in the proportion of children of poor growth, especially stature, between families containing 4 and 6 children.

The relative importance of the number of children as opposed to total household size is illustrated in Fig. 3, in which households are subdivided on the basis both of number of adults and number of children present. It can be seen that for a given number of children the number of adults in the home has little relation to the growth of children, especially where the number of children is large. On the other hand, there is a marked increase in the prevalence of poor growth in homes with more children than with less, irrespective of the number of adults. As homes containing more than one nuclear family with children under 15 years are excluded, it is clear that it is the size of the family rather than total number of people in the home that determines the prevalence of poor growth. 


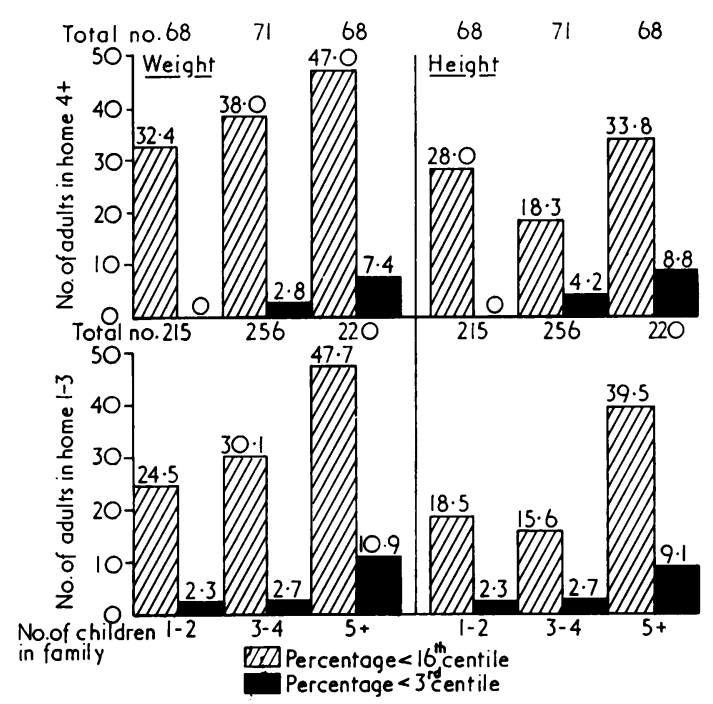

FIG. 3.-Percentage of children in $<3 r$ and $<16$ th growth centiles in families of different sizes and effect cf presence of other adults in home.

Absence of mother. There was no significant relation between absence of mother and growth retardation. This is at first sight surprising in view of the relation between child-mother separation and physical failure to thrive (Bowlby, 1951). The reason for this is probably that in St. Helena most of these children live with a close relative (usually grandmother) from an early age, i.e. there is a stable and affectionate mother substitute.

\section{Discussion}

The most important adverse factors affecting growth in St. Helena are shown to be social. In particular we were able to isolate the size of the nuclear family as an important correlate with suboptimal weight and height. This effect over-rides the smaller one of household size, and suggests that physical overcrowding is of much less importance than the dynamics of the family structure. Lacey and Parkin (1974b) have shown the importance of 'standard of care' in promoting normal growth, but these standards are hard to assess, and prone to bias by the observer, especially where social class attitudes differ.

Of considerable interest is the sharp rise in the prevalence of suboptimal growth patterns in families containing more than 4 children. This is in surprisingly close agreement with observations in Newcastle upon Tyne (Lacey and Parkin, 1974b) and with the National Child Development Survey (Davie, Butler, and Goldstein, 1972). We can postulate a 'threshold of coping', i.e. the number of children which the majority of families in a society can cope with as judged by prevalence of short stature. This could provide a useful concept for family planning and social welfare services in communities where resources are limited.

The actual mechanism causing poorer growth patterns in larger families needs further exploration. Certainly in St. Helena there was good calorie intake in general, but vitamin and protein intake may have been poor in large families even though no frank deficiency states were seen. Against this theory we can note the surprisingly slight relationto social class and therefore to degrees of affluence. Emotional deprivation is clearly another possibility not entirely separable from poor physical care.

Clearly more refined research is needed into the relation between patterns of care and fulfilment of growth potential. If we are to improve the upbringing of children in any society, growth rates can give us an important, though crude, index of quality of care and indicate the areas in which we must concentrate our help.

I thank especially Dr. J. Noakes and the teachers of St. Helena for their help; Dr. J. M. Parkin for encouragement and advice on the presentation of this information; above all the kind people of St. Helena for whom this work was done.

\section{REFERENCES}

Bowlby, J. (1951). Maternal care and mental health. Monograph Series, No. 2. World Health Organization, Geneva.

Davie, R., Butler, N., and Goldstein, M. (1972). From Birth to Seven. Second Report of the National Child Development Study, p. 31. Longmans, London.

Lacey, K. A., and Parkin, J. M. (1974a). Causes of short stature. Lancet, 1, 42.

Lacey, K. A., and Parkin, J. M. (1974b). The normal short child. Archives of Disease in Childhood, 49, 417.

Miller, F. J. W., Billewicz, W. Z., and Thompson, A. M. (1972). Growth from birth to adult life of $\mathbf{4 4 2}$ Newcastle upon Tyne children. British fournal of Preventive and Social Medicine, 26, 224.

Neligan, G., Prudham, D., and Steiner, M. (1974). The Formative Years, p. 84. Oxford University Press, London.

Shine, I. (1970). Serendipity in St. Helena. Pergamon Press, Oxford.

Tanner, J. M., Whitehouse, R. M., and Takaishi, M. (1966). Standards from birth to maturity for height, weight, height velocity, and weight velocity: British children 1965 . Archives of Disease in Childhood, 41, 454.

Correspondence to Dr. C. D. Moyes, Department of Child Health, University Hospital of Wales, Cardiff. 